\title{
DESCRIPTIONS OF SIX NEW GENERA AND THIRTY-ONE NEW SPECIES OF ICHNEUMON FLIES.
}

\author{
By H. L. Viereck,
}

Bureau of Entomology, U. S. Department of Agriculture, Washington, D. C.

This is one of a series of papers based upon new genera and species of Ichneumonoidea or Ichneumon flies, in most cases contained in the collections of the U.S. National Nuseum and of such a nature as to call for their early publication.

\section{Family BRACONIDE.}

\section{DOLICHOGENIDEA, new subgenus.}

Head with the facial line greater than the transfacial line, otherwise as in Apanteles Foerster.

Type.-Apanteles (Dolichogenidea) banksi, new species.

APANTELES (DOLICHOGENIDEA) BANKSI, new species.

Female.-Length $2.5 \mathrm{~mm}$; black and shining; head dullish, mandibles mostly reddish stramineous, joints beyond the second in both maxillary and labial palpi stramineous; dorsulum dullish, scutel shining, sparsely punctured, the punctures as many as ten or more puncture widths apart, wings whitish except the costa, which is stramineous between the stigma and the base of the wing and brown beyond the stigma, the stigma, which is brown except for a basal yellow mark and the radius, transverse cubitus and third abscissa of the cubitus, which are infuscated, fore legs stramineous beyond the trochanters, mid-legs with their femora mostly black, their tibiæ and tarsi mostly stramineous, hind legs black or blackish except for a basal stramineous annulus to their tibiæ and basal joint of tarsi; propodeum rather dullish except for the poorly circumscribed areola, which is more shining and mostly represented by a depressed basin, virtually exareolate except for the areola and basal area, punctured; first tergal plate almost quadrate, parallel sided, shining, punctured, medially impressed though slightly, second tergal 
plate shining, punctured laterally, nearly four times as wide at base as long down the middle, its apical margin not well defined, arcuate so that it is narrower laterally than medially measured anteroposteriorly, exserted portion of the sheaths of the ovipositor practically as long as the tergum of the abdomen proper.

Type.-Cat. No. 13510 , U.S.N.M.

Type-locality.-Chesapeake Beach, Maryland, September 4, 1910, collected by Nathan Banks.

Named for Mr. Nathan Banks.

APANTELES (PROTAPANTELES) AFRICANUS, new species.

Belongs to the same group as Apanteles (Protapanteles) fulvipes (Haliday, Marshall), with which it agrees in most particulars except as set forth in the following description:

Female.-Length $3 \mathrm{~mm}$.; first dorsal plate parallel sided or nearly so to the middle, hardly twice as long as wide at base; second dorsal plate poorly circumscribed, narrower at base than long down its middle, nearly twice as wide at apex as long down the middle, membranous portion of first and second segments more or less pale, third tergal segment more or less pale; radius apparently twice as long as the transverse cubitus, most of the veins and stigma blackish in the fore wings, hind tibiæ tipped with fuscous, hind tarsi mostly fuscous.

Male.-Similar to the female.

Type.-Cat. No. 13491, U.S.N.M.

Type-locality.-Pretoria, Transvaal.

Received from C. W. Howard.

APANTELES (PROTAPANTELES) BEDELLI $Æ$, new species.

Female.-Length $1.75 \mathrm{~mm}$.; facial line not greater than the transfacial line, head black, antennæ blackish, palpi mostly pale; thorax black including tegulæ and coxæ, wings almost colorless, tinged with brown, basal abscissa of costa stramineous, stigma and poststigmatic costa dark brown, most other veins in forewings stramineous tinged with fuscous; the radius, transverse cubitus and third abscissa of cubitus darker than the rest excepting the costa, femora and tibiæ mostly stramineous to reddish, the hind femora and tibiæ tipped with fuscous, their tarsi fuscous, or deep brown; propodeum shining, rugulose, with a median longitudinal carina; first tergal plate hardly twice as long as wide at base, apparently as wide at extreme apex as at the corresponding part of its base, the almost parallel sides bulging somewhat beyond the middle and finally sharply recurved so that the plate is as wide at apex as at base, dullish, mostly rugulose; second tergal plate shorter than the third tergal segment, but little wider at base than long down its 
middle, its apical width at least one and one-half times the basal width, its sides oblique to the middle beyond which they are almost parallel, in sculpture similar to the first tergal plate, remaining tergal segments virtually smooth and shining throughout, only the third with apparent sculpture and in this confined to extreme base, exserted portion of sheaths of the ovipositor nearly as long as the first tergal segment, abdomen black or blackish throughout.

Male.-Similar, its first tergal plate apparently twice as long as wide at base and parallel sided throughout, the second tergal plate hardly as wide at base as long down the middle; femora more or less blackish, mid tibiæ with apical infuscation, hind tibiæ infuscated except for a pale basal annulus.

Type.-Cat. No. 13501, U.S.N.M.

Type-locality.-Washington, District of Columbia.

"Bred from Bedellia, September 9, 1910; T. H. Jones, collector."

\section{APANTELES (PROTAPANTELES) BENEFICUS, new species.}

Female.-Length $1.5 \mathrm{~mm}$; belongs to a group of species of which the American Apanteles (Protapanteles) radiatus Ashmead is a representative, but from that species it may be readily distinguished as follows: Scape and rest of antennæ black, tegument of head black; thorax black, dorsulum dullish, indistinctly sculptured, wings hyaline, apparently tinged with whitish, transverse cubitus not forming an angle at its junction with the radius, anterior coxæ blackish as are all the other coxæ, middle femora brownish, fourth and fifth joints of middle tarsi fuscous, hind legs black or blackish almost throughout; propodeum almost completely smooth and shining all over; first dorsal plate apparently twice as long down the middle as wide at base and virtually smooth and polished throughout, sculptureless, second plate not much narrower at base than long down the middle, also smooth, polished, and sculptureless, the first and second tergal segments rather brownish, rest of tergal segments blackish.

Male.-Quite similar to the female, agreeing in all essential particulars.

Type-Cat. No. 13492, U.S.N.M.

Type-locality.-Mozambique, Portuguese East Africa.

Received from C. W. Howard, who sent them to the U.S. Department of Agriculture, Bureau of Entomology.

\section{APANTELES (PROTAPANTELES) CHRYSIPPI, new species.}

Belongs to a group of species represented by Apanteles (Protapanteles) solitarius (Ratzeburg) Marshall.

Female.-Length $2.25 \mathrm{~mm}$; head black and shining, antennæ blackish or dark brown throughout, facial line not longer than the transfacial line, mandibles brownish, palpi mostly pale, mesonotum mostly dullish and closely punctured, many of the interstices narrower 
than the dianseter of the average puncture, scutel shining, not so closely, but more distinctly punctured than the mesonotum, the punctures larger, most of the veins stramineous with a brownish tinge, stigma and costa brown, membrane almost colorless, legs mostly stramineous with a brownish tinge, tarsi brownish, hind femora with a brownish tip, all tibiæ with a more or less developed brownish tip, tegulæ dark brown, fore and mid-coxæ brownish, hind coxæ black; radius a little longer than transverse cubitus, forming a distinct angle with the latter; propodeum irregularly reticulate, without a median longitudinal carina; tergum brownish suffused with black, apical half of first plate punctured, the punctures apparently larger than but not so regular as on the scutel; second plate poorly sculptured with illdefined striæ, shining; middle two-fourths of basal half of third tergal segment with a lunate striate area, exserted portion of sheaths of the ovipositor hardly longer than onychium of mid-legs.

Male.-The third tergal segment almost sculptureless; otherwise very similar to the female.

Type.-Cat. No. 13490, U.S.N.M.

Type-locality.-Mozambique, Portuguese East Africa.

"Reared from larvæ, Danais chrysippus." Received from Mr. C. W. Howard.

APANTELES (PROTAPANTELES) CINCTIFORMIS, new species.

Female.-Length $3 \mathrm{~mm}$.; facial line shorter than the transfacial line, head black, scape bright testaceous, rest of antennæ mostly dark brownish, mandibles, palpi, tegulæ, legs including coxæ and trochanters, and membranous portion of first tergal segment all more or less stramineous to reddish stramineous; thorax with the vertical axis equal to the transverse axis, wings transparent tinged with brown, stigma and costa beyond the stigma very dark brown, third abscissa of the radius darker than and a little longer than the second, transverse cubitus and radius concolorous with the third abscissa of the cubitus, scutel smooth and shining, punctate, the punctures several puncture widths apart, not well defined; first tergal plate about one and one-half times as long down the middle as wide at base, parallel sided to the apical third, from thereon with the sides oblique, its apex about two-thirds as wide as its base, rugulose, second tergal plate trapezoidal, rather striate, as long down the middle as the first tergal plate is wide at apex, second tergal segment reddish like the third and fourth and sides of fifth and sixth, distinctly shorter than the third, exserted portion of sheaths of the ovipositor about as long as the first tergal segment.

Tupe.-Cat. No. 13502, U.S.N.M.

Type-locality.-Great Falls, Virginia, June 18; collected by Nathan Banks, 
APANTELES (PROTAPANTELES) GRIFFINI, new species.

Female.-Length $1.75 \mathrm{~mm}$. Related to Apanteles halli but with the second dorsal plate mostly sculptured and with the color more as in A panteles lroviceps to which latter species it is evidently more closely related than to the former. From Apanteles lrviceps it may be distinguished by the smaller size, the presence of a more of less smooth sculptureless area on the second dorsal segment, by the apical half of the hind femora being mostly infuscated, by the first joint of the flagel being almost stramineous beneath and by the almost entirely black abdomen; ovipositor normally not exserted

Male.-Sufficiently similar to the opposite sex to be easily asscciated therewith, flagel blackish throughout.

Type.-Cat. No. 13482, U.S.N.M.

Type-locality.-Quogue, New York.

Eight females and four females from the type-locality "Griffin collector, Webster No. 6268." Received from the Bureau of Entomology, U. S. Department of Agriculture. "Were sent as having overcome a scourge of cutworms." F. M. Webster.

Named for the collector, Mr. N. E. Griffin.

Genus PSEUDAPANTELES Ashmead.

Type.-Pseudapanteles annulicornis Ashmead.

APANTELES (PSEUDAPANTELES) CONSIMILIS, new species.

Pseudapanteles consimilis Ashmead, Manuscript 1900 (1899), Smith's Ins., N. J., p. 593.

Female.-Length $3.5 \mathrm{~mm}$. Flagel blackish brown throughout, scape and pedicel mostly yellowish, head appearing wider than long, mandibles yellowish, tipped with castaneous, palpi whitish, tegulæ, base of wings, fore and mid-legs, hind femora, hind coxæ apically, membranous portion of first and second segments and sides and venter of third segment all mostly stramineous, hind coxæ basally castaneous, hind tibiæ pale yellowish at base merging into castaneous, then into blackish brown, hind tarsi dark brown, each joint pale at base; otherwise mostly black, wings hyaline, stigma uniformly dark brown; first abscissa of radius, transverse cubitus, and third abscissa of cubitus brownish; second abscissa of externo-medial, first abscissa of discoidal vein, nervellus and costa more or less stramineous to brownish, other veins almost colorless; propodeum mostly rugose, smooth and polished at base and with a salient longitudinal median carina; first dorsal plate half again as long as wide at apex, where it it is a little wider than at base, nearly parallel sided throughout, its basal third forming an obtuse angle with the apical two-thirds in profile, the basal third mostly striate and smooth, the apical two-thirds $80796^{\circ}$-Proc.N.M.vol.40-11-—12 
mostly rugose but becoming striate apically, the apical edge interrupted by a smooth area in the middle, second dorsal plate about four times as wide as long down the middle and rugose, though not as strongly as the preceding plate, the third dorsal segment nearly three times as wide at base as long down the middle and almost entirely smooth; exserted portion of ovipositor about as long as the abdomen above.

Type.-Cat. No. 13486, U.S.N.M.

Type-locality.-Long Island, New York. Ashmead collection.

APANTELES (PSEUDAPANTELES) ETIELLF, new species.

Facial line not longer than the transfacial line; vertical axis of thorax virtually as great as the transverse axis; propodeum smooth and polished with a distinct median longitudinal carina; first tergal plate smooth and polished like the second, less than twice as long down the middle as wide at base and distinctly narrower at apex than at base, its sides gradually converging from base to apex, only half as wide at apex as at base, second plate at least four times as wide at apex as long down the middle, its apical edge slightly sinuate, hardly as wide at base as long down the middle.

Male.-Length $2.5 \mathrm{~mm}$., black except as follows: Palpi mostly stramineous, tegulæ almost colorless tinged with brown, fore femora apically, their tibiæ and tarsi mostly, testaceous; mid and hind tibiæ basally pale, together with their tarsi mostly dusky, wings whitish, first abscissa of costa stramineous, stigma and costa beyond dark brown, radius at least twice as long as the tranverse cubitus, the third abscissa of the cubitus distinctly shorter than the second, these veins, together with the recurrent vein, first abscissa of discoidal, second abscissa of median and transverse median vein, all tinged with brown.

Type.-Cat. No. 13503 , U.S.N.M.

Type-locality.-Pullman, Washington.

Received from the U. S. Department of Agriculture, Bureau of Entomology, under “Webster No. 5935, August 10, 1909 ”; J. A. Hyslop, collector. Ex. Etiella schisticolor.

CHELONUS KNABI, new species.

Female.-Length $5.5 \mathrm{~mm}$; antennæ 34 -jointed, joints of the flagel black, finely longitudinally striate, at least twice as long as thick, subequal in length, each joint a little shorter than the one preceding, though from the fourth to the eleventh the joints are nearly equal in length to their immediate predecessor, that is, with the fourth nearly equal to the fifth, the fifth nearly equal to the sixth and so on, scape and pedicel also black, head, including clypeus black, face transversely rugose, with a median longitudinal more or less distinct carina extending from the base or near the base of the clypeus to the base of the 
frontal basin, clypeus rather smooth compared with the face, covered with shallow pits, its anterior edge truncate, the truncature about as wide as the anterior edge adjoining, mandibles mostly castaneous, palpi mostly fuscous; thorax black, mostly reticulate all over; propodeum rounded off, coarsely reticulate, the lateral spines represented by a kind of arcuate buttress, base of propodeum with a median longitudinal carina extending from the base of the superior aspect to the beginning of the posterior aspect and flanked on either side by a carina that attains the apex toward which it converges though nearly parallel to its fellow of the opposite side, wings transparent fuscous except proximad to the base of the stigma where the membrane is nearly colorless and the veins mostly stramineous, distad to the base of the stigma the veins are mostly fuscous like the stigma, coxæ and proximal hind trochanters mostly black, rest of trochanters mostly ferruginous like all the femora, hind tibiæ ferruginous except a fuscous stain at base and an apical blackish band enveloping the apical third, remaining tibiæ ferruginous; abdomen black with little more than its basal third ferruginous, the ferruginous color of its base extending laterally to a little beyond the middle, the corresponding ventral area castaneous, the paired carinæ of the base of the abdomen extending nearly to the middle of the ferruginous area where they become lost among the numerous longitudinal reticulo-striations which continue to near the apical concavity where they are replaced by a kind of reticulation mixed with rugosities, the end of the carapace somewhat truncated and with a vague longitudinal sulcus down its middle; pubescence generally distributed, almost imperceptible, whitish or pale ochreous; tarsi fuscous or blackish almost throughout.

Male.-About as long as the female, differing chiefly as follows: Antennæ 33 -jointed, carapace not so markedly vaulted, propodeal carinæ and basal carinæ of carapace indistinctly defined, hind tibiæ ferruginous throughout at base, apex of carapace rounded off, not at all parted by a fissure transversely or by a vague sulcus longitudinally, basal two-thirds of carapace mostly ferruginous, the remaining portion mostly black; facial carina indistinct or wanting.

Type.-Cat. No. 13487, U.S.N.M.

Type-locality.-Four Mile Run, Virginia.

Three specimens, two females and one male, collected May 30, 1910 , by Frederick Knab, for whom the species is named.

In many particulars this species agrees with Chelonus laticinctus Cresson, of which I had the type for comparison. Of the British species it has characters in common with Chelonus wesmaelii Curtis. From each of these, however, it differs abundantly, as may be gleaned from perusing the above description.

The female paratopotype is essentially like the type female, though wanting the basal stain to the hind tibiæ. 
CRYPTOXILOS, new genus.

Belongs to the Euphorinæ and has characters in common with Peristenus Foerster. Apparently, however, more nearly related to Loxocephalus Foerster.

Transfacial line at least one-sixth longer than the facial line, clypeus rather hidden and partly covered by the closed mandibles which latter are falcate and edentate and inserted back of a point on a line with the middle of the eyes, malar line a little longer than width of mandibles at base, antennæ 12 -jointed, not much longer than the head and thorax together, inserted close to and opposite the middle of the eyes, the space between the scrobe and the eye not as wide as the scrobe, head as seen from above at least twice as wide as long antero-posteriorly, occipital carina complete; notauli converging to the scutel short of which they unite to form a triangular lobe, recurrent vein wanting, transverse cubitus incomplete, not meeting the cubitus; petiole almost parallel sided not produced laterally.

Otherwise similar to Peristenus Foerster.

Type.-Cryptoxilos dichromorphus, new species.

CRYPTOXILOS DICHROMORPHUS, new species.

Male.-Length $1.25 \mathrm{~mm}$; castaneous, shining. Face mostly yellowish beneath the antennæ, divided by a low carina that extends from the anterior ocellus almost to the clypeus, front indistinctly pitted between the scrobes, scape but little longer than the pedicel, first joint of flagel longer than the scape but a little shorter than the second joint of the flagel, remaining joints subequal, excepting the apical joint which is the longest, antennæ stramineous, infuscated, ocelli nearly equidistant and distinctly nearer to each other than to the nearest point on the eyes; thorax shining and somewhat darker than the occiput, wings transparent, faintly infuscated, veins stramineous, stigma very dark brown, forming an obtuse angled triangle and nearly as large as the radial cell, cubitus extending as far beyond the point where the transverse cubitus would meet as the transverse cubitus is long, submedian vein parallel to the median and not extending beyond the basal; propodeum reticulate, with a petiolarea; tegulæ and legs stramineous, basal hind tarsus approximately as long as the next three joints combined, claws apparently simple, empodium of hind onychium apparently nearly as long as the claws; abdomen brownish, smooth and polished except for the petiole which has three dorsal, longitudinal, straight, parallel carinæ, second segment cask-shaped, a little longer than the petiole and at least twice as long as the combined length of the segments beyond, the segments beyond the second apparently not differentiated, tip of abdomen and 
protruding genitalia stramineous, claspers simple, nearly parallel sided, tapering, rounded at tip.

Type.-Cat. No. 13497, U.S.N.M.

Type-locality.-Bahia, Brazil.

Type collected on cotton, March 16, 1883; A. Koebele, collector.

DIACHASMA CRAWFQRDI, new species.

Female.-Length $6 \mathrm{~mm}$.; sheaths of the ovipositor as long as the body. Head black, antennæ blackish, 53-jointed, face with a median carina extending from as far below the anterior ocellus as the same is wide to a point approximately halfway between the antennal line and the clypeus where the carina becomes reduced so that it is lost on the convexity of the face above the clypeus, clypeus with a median longitudinal welt, the lateral free edges of the clypeus rather reflexed or upturned, clypeus medially terminating in an obtuse angle which is flanked by a sinuosity that is bounded by the lowest corners of the clypeus, which latter are angular, apical half of mandibles more or less brownish, palpi stramineous as are the præpisternum and most of the fore coxæ, with the palpi paler, mandibles but little wider at base than at apex; rest of thorax darker stramineous, scutellar fovea divided longitudinally by a carina, wings infuscated, stigma and veins blackish, radius fully developed throughout and attaining the margin of the wing as far or nearly as far from the extreme tip as the second transverse cubitus is long, stigma forming an obtuce angle on its lower edge and about three times as wide as high, radius inserted a little beyond the middle of the stigma, nervellus almost interstitial, anal cell in hind wings nearly divided by a vein that is almost parallel to the nervellus, mid and hind coxæ stramineous at base and blackish apically; proximal trochanters, distal trochanters of hind legs and most or all of femora and tibiæ black; distal trochanters of fore and mid-legs castaneous as is the base of fore and mid-femora, first, second, third, and fourth joints of fore and mid-tarsi more or less stramineous, fore and mid-onychiæ blackish as are their claws and empodia, hind tarsi blackish throughout; abdomen mostly rather ferruginous, the first dorsal segment with four carinæ defining five channels, the inner carinæ arched and terminating a little beyond the middle of the segment, the outer carinæ extending from base to apex and parallel to the outer margin, sheaths of the ovipositor blackish, ovipositor castaneous.

Type.-Female, Cat. No. 13484, U.S.N.M.

Type-locality.-Cuernavaca, Mexico. Sent to the Bureau of Entomology, U. S. Department of Agriculture, by Mr. D. L. Crawford, who observes that the specimen was "taken while stinging mango with maggots in it." This species is probably a parasite of Anastrepha ludens Loew.

Named for D. L. Crawford. 


\section{DIAERETUS NIPPONENSIS, new species.}

Male.-Length $1.5 \mathrm{~mm}$. Related to Diæretus piceus Cresson from which it may be distinguished by the costulæ diverging from the apex of the propodeum not at right angles to the median longitudinal carina and by the nonprojecting petiolar spiracles.

Female.-Flagel 11-jointed, costulæ at right angles to the median longitudinal carina on propodeum, otherwise very as in the male.

Type-Cat. No. 13495, U.S.N.M.

Type-locality.-Japan. Received by the U. S. Department of Agriculture, Bureau of Entomology, from Mr. G. Compere, under data as follows: Cabbage aphis, Japan, 1906; G. Compere collector; No. 15050 .

\section{DOLICHOZELE, new genus.}

This genus has characters in common with Zele Curtis and Leptozele Cameron. Compared with Zele Curtis this genus differs essentially as follows: Clypeus broadly, shallowly emarginate, almost truncate, hind ocelli larger than the anterior ocellus and nearer the anterior ocellus than to each other or nearest point on eye margin, occiput immargined; radius received by the stigma distinetly beyond the middle, second discoidal cell completely closed, submedian cell with a brownish spot on the median vein and on the submedian vein, hind coxæ shorter than the first abdominal segment; first abdominal segment as long as the next two combined, with its spiracles nearly twice as far beyond the base as they are distant from each other.

Type.-Dolichozele koebelei, new species.

\section{DOLICHOZELE KOEBELEI, new species.}

Female.-Length, $9 \mathrm{~mm}$. Resembles Zele testaceator Curtis, but differs as follows: Penultimate joint of $\mathrm{m}$. p. distinctly longer than the end joint, scape and pedicel combined hardly two-thirds the length of the first joint of the flagel but about as long as the second joint of the flagel, antennæ 52-jointed, vertex with a blackish band extending from eye to eye; stigma infuscated, propodeum with concentric arcuate striæ; sheaths of the ovipositor about as long as the second abdominal segment. Color in general dull stramineous not at all reddish.

Type.-Cat. No. 13496, U.S.N.M.

Type-locality.-Pernambuco, Benito Province, Brazil. No. 168, January 31, 1883; A. Koebele.

Named for Mr. A. Koebele.

\section{HABROBRACON BENEFICIENTIOR, new species.}

The affinities of this species are with $H$. brevicornis (Wesmæl).

Female.-Length $2.5 \mathrm{~mm}$.; sheaths of the ovipositor $0.5 \mathrm{~mm}$. long. From Marshall's description of $H$. brevicornis (Wesmæl) this differs 
essentially as follows: Color very as in Microbracon howardi Viereck, but tinged with testaceous and with yellowish stramineous color replacing the yellow, wings transparent tinged with brownish, stigma and costal vein brownish, other veins stramineous tinged with brown; third, fourth, and fifth tergal segments partly brownish laterally.

Male.-Similar to the opposite sex but with the dark regions mostly blackish.

\section{Type.-Cat. No. 13494, U.S.N.M.}

Type-locality._- "Busi, just inland from Beira, Mozambique." Portuguese East Africa, "From a maize storehouse." Presumably parasitic on one of the Coleopterons that feed upon maize. In a series of specimens the darkening of the third, fourth, and fifth tergal segments is seen to be sometimes quite extensive, again wanting or almost wanting, at least on the third segment. The first tergal segment, on the other hand, is apparently always yellowish or whitish yellow.

\section{HORMIOPTERUS GRACILIFORMUS, new species.}

Related to $H$. fasciatus Ashmead, compared with the type of which it differs as follows:

Female.-Scarcely $2.5 \mathrm{~mm}$. long; exserted portion of sheaths of ovipositor approximately $0.5 \mathrm{~mm}$. long. Tergum hardly striate, first tergal segment virtually simple and rounded off at base except for the rudimentary dorsal and lateral carinæ, the latter obliquely extending backward and downward, attaining the lower edge of the first tergal segment at a point about one-fourth the length of the lower edge from the base of the segment; in both species the metanotum (postscutel) as seen from the side of the specimen is produced into a low thorn-like process with the apex pointed toward the propodeum.

Mate.-Similar to the female.

Type.-Cat. No. 13500 , U.S.N.M.

Type-locality.-Wellington, Kansas.

Received from U. S. Department of Agriculture, Bureau of Entomology, under Webster Nos. 5473, cage $119 ; 5472$, cage $330 ; 6515$, cage $497 ; 5476$, cage $294 ; 5473$, cage $300 ; 5422$, cage $121 ;$ T. H. Parks collector; reared from an eurytomid in Agropyron.

MACROCENTRUS (AMICROPLUS) CRAMBIVORUS, new species.

Female.-Length, $3 \mathrm{~mm}$; sheath of the ovipositor $4 \mathrm{~mm}$. long. Head black, mouth and palpi stramineous, infuscated; scape, pedicel and first joint of flagel dark stramineous, rest of antennæ brownish to blackish; antennæ 34-jointed; thorax, coxæ and trochanters stramineous, rest of legs rather brownish stramineous, claws black; middle lobe of dorsulum hardly higher than the lateral lobes, notauli 
almost smooth; propodeum granular; wings transparent, faintly infuscated, second abscissa of radius about as long as the first transverse cubitus; first, second, and third dorsal abdominal segments stramineous, the second a little shorter than the first and fused with the third, second segment smooth and polished, remaining segments black, lateral furrows of second segment distinct, simple and extending a little back of the middle of the segment, sheaths of the ovipositor blackish, ovipositor dark stramineous.

Male.-Similar to the female but differing as follows: Antennæ 38jointed, flagel blackish throughout; thorax black; first, second, and third tergal segments black.

Type.-Cat. No. 13481, U.S.N.M.

Type-locality.-Corry, Pennsylvania. Received from the Bureau of Entomology, U. S. Department of Agriculture, "Webster No. 6703," lot No. 31 and 41; W. W. Yothers, collector; reared from larvæ of Crambus. The paratypes are from the type-locality excepting some females as follows: "No. 196 Ex. Crambus caliginosus," "No. 16920," “"No. 705, June 23," "From unknown pupa, August 18, 1872," and additional specimens from Jacksonville, Florida, and Washington, District of Columbia. Ashmead collection. The atopoparatypes (paratypes not from type-locality) paler than the types and paratopotypes, but in color pattern, structure, and sculpture apparently typical.

\section{MICROBRACON HOWARDI, new species.}

Belongs to that catagory of Marshall's section I having a median longitudinal carina on the propodeum (Tropidobracon Ashmead). Compares well with (Bracon) Microbracon fulvipes Nees, from which it differs as follows:

Female.-Length $3.5 \mathrm{~mm}$.; sheaths of the ovipositor $5.5 \mathrm{~mm}$. long; mostly stramineous and yellow, head and thorax shining, abdomen dullish; head mostly stramineous, except for the orbits which are more or less yellow and the interocellar area which is black, vertex exceedingly finely sculptured; dorsulum indistinctly sculptured, its median longitudinal two-fourths brownish anteriorly, yellowish posteriorly, the outer fourths mostly blackish, scutel yellow, rest of thorax stramineous maculated with brownish except the mesepisternum which is mostly yellow, legs stramineous excepting the tarsi which are brownish; propodeum mostly brown, stramineous laterally, perfectly smooth and polished, the carina distinctly developed throughout; tergum of abdomen mostly granular, yellowish and stramineous, in part with brownish stains, second tergal segment mostly reticulate, the third with the reticulations so arranged as almost to make well defined striæ.

Type.-Cat. No. 13493, U.S.N.M.

Type-locality.-Chai-Chai, Mozambique, Portuguese East Africa. 
Received from C. W. Howard by the U. S. Department of Agriculture, Bureau of Entomology.

MICROPLITIS MELIANAE, new species.

Male.-Length, $2.5 \mathrm{~mm}$. Related to Microplitis cinctus Ashmead, compared with the type of which it differs chiefly as follows: Antennæ blackish throughout, tegulæ and all coxæ black; scutel shining, with ill-defined punctures; first tergal plate nearly twice as wide at base as at apex, parallel sided to beyond the middle and nearly twice as long as wide at base, smooth, sculptureless and shining, remaining segments smooth and shining virtually sculptureless, tergum blackish, the membranous portion of first and second segment rather brownish; hind femora and tibiæ not concolorous throughout.

Type.-Cat. No. 13508, U.S.N.M.

Type-locality.-Grand River, Iowa.

"From Meliana albilinea caterpillar of V stage."

Experiment 342, July 5, 1910, and Experiment 601, September 20, 1910; R. L. Webster.

\section{PLATYSPATHIUS, new genus.}

Apparently related to Spathius from which it may be distinguished as follows: Greatest distance between lowest point on outer eye margin and occipital carinæ about one and one-half times the greatest distance between uppermost point of outer eye margin and the occipital carina; notauli converging toward the hind third of the mesonotum, at the beginning of which they terminate, the notauli as far as they go distinct and only half as far from each other where they end as where they begin, fore wings with the median vein strongly bent or curved toward the submedian which it almost touches, subdiscoidal vein interstitial with the median; first dorsal segment depressed, apparently three times as wide at base as thick dorso-ventrally, approximately half as wide at base as at apex and nearly four times as long down the middle as wide at base, uniformly depressed throughout; second dorsal segment obtrapezoidal, its apical margin indistinctly arched back so that this segment is about as long down the middle as wide at base though laterally shorter than wide at base; suture between second and third segments indistinct, third segment shorter down the middle than laterally, gaster (abdomen beyond the petiole or first segment) bulbous.

Type.-Platyspathius pictipennis, new species.

PLATYSPATHIUS PICTIPENNIS, new species.

Female.-Length, $4.5 \mathrm{~mm}$.; sheaths of the ovipositor $2.5 \mathrm{~mm}$. long; mostly dark castaneous, finely sculptured, dullish to shining; antennæ 26-jointed, rather stramineous except for the 21st to 26th joints which are rather blackish, joints of the flagel subequal, the first a 
little longer than the second and nearly as long as the scape and pedicel combined; posterior third of mesonotum with a faint median longitudinal carina, fore wings mostly infuscated, with a whitish fascia extending from near the middle of the anterior margin of the costal cell nearly perpendicularly to the hind edge of the wing; basal third of stigma and about one-fifth of the first cubital cell adjoining, whitish, this latter area comprising the first part of a second fascia which reappears from the junction of the cubitus and the first transverse cubitus to the hind margin of the wing; there is a hyaline spot in the marginal cell and the tip of the wing is washed out or almost hyaline; most veins in fore wings brownish, rest of stigma blackish; hind wings colorless except for most of the venation which is stramineous; tegulæ stramineous; propodeum with the upper aspect separated from the lateral nearly parallel sided aspects by a longitudinal carina on each side, the lateral areas hardly more than one-fourth the width of the median area at base, the latter with a short median longitudinal carina at base; first dorsal segment almost triangularly produced laterally at base into a kind of buttress, first and second tergal segments dullish, the following segments of the tergum blackish and more or less shining.

Male.- Similar to the other sex but lacking the lateral processes to the first tergal segment and with the lateral aspects of the propodeum not so well circumscribed.

Type.-Cat. No. 13489, U.S.N.M.

Type-locality.-Xalasi (Maputo), Lorenzo Marquez, Portuguese East Africa.

Received from C. W. Howard, by the U. S. Department of Agriculture, Bureau of Entomology.

The maculation of the fore wings in this species recalls the Tineoid genus Argyresthia.

POLYSTENIDEA, nevv genus.

May prove to be the same as Polystenus Foerster, to which it seems to be more nearly related than to any other genus.

Head back of the eyes extending nearly to or a little beyond the eye as seen in profile, antennæ not more than 14-jointed; legs slender, basal joint of hind tarsi nearly as long as the next three joints combined, disk of propodeum and disk of first dorsal segment approximately equal in length, notauli wanting; abdomen with only four segments visible above. In other particulars very as in Hecabolus Curtis.

Type.-Polystenidea parksi, new species.

POLYSTENIDEA PARKSI, new species.

Male.-Length $2.5 \mathrm{~mm}$. Head black, finely sculptured, rather dullish, as seen from above, extending a little beyond outside line of 
eyes back of the eyes, as seen from in front wider than long or with the facial line shorter than the transfacial line, ocelli not prominent, equidistant or nearly so, about one-third as far from each other as from the nearest eye margin, antennæ 13 -jointed, scape and pedicel pale, flagel brownish, joints subequal, the first joint a little longer than the second, mandibles and palpi mostly pale; thorax castaneous mostly blackish above, finely sculptured; propodeum with a median longitudinal carina that extends to a little beyond the middle and then bifurcates to form a nearly parallel sided petiolarea; hind wings without a parastigma, tegulæ, stigma, and most veins rather dusky stramineous, legs stramineous; abdomen finely sculptured, castaneous laterally, mostly blackish above, basal facet of first dorsal segment bounded by a distinct carina and rather triangular with a delicate median carina extending from its apex to the apex of the first segment, first dorsal segment trapezoidal, nearly two-thirds as long as the second segment which latter is trapezoidal although nearly quadrate and at least one-third again as long as the third, the third one-third again as long as the fourth, second segment with a faint incomplete longitudinal median carina.

Type.-Cat. No. 13488, U.S.N.M.

Type-locality.-Wellington, Kansas.

Received from the U. S. Department of Agriculture, Bureau of Entomology. " "Swept from Agropyron, April 9, 1910;" T. H. Parks, collector.

Named for Mr. T. H. Parks.

POLYSTENIDEA IMETACOMET, new species.

Female.-Length $1.5 \mathrm{~mm}$. Head black, rather smooth and shining; as seen from above, extending nearly to the outside line of the eyes back of the eyes, antennæ 14-jointed, scape, pedicel, and mandibles mostly pale; thorax black, legs mostly stramineous, rather infuscated; exserted portion of ovipositor as seen from above not as long as the apical segment of the abdomen.

In other points this spcies answers well to the description of the genotype as described above.

Type.-Connecticut Agricultural Experiment Station, New Haven, Connecticut.

Type-locality.-New Haven, Connecticut; collected by the writer July 4, 1905.

\section{STENOPLEURA, new genus.}

Related to Protapanteles Ashmead, from which it may be disguished in the depressed thorax which is apparently wider from side to side than thick dorso-ventrally; lower edge of scrobe a little below or on a line with an imaginary straight line drawn across the face and 
connecting the middle point of each inner eye margin. Habitus quite different from Protapanteles, Apanteles, and Pseudapanteles, very suggestive of Goniozus and allied genera in the Bethylidæ.

The male of the type-species was not known to the describer at the time the species was first described. At any rate, it has apparently never been described. It differs from the female as described by Cameron especially in having the joints of the flagel at least three times as long as wide at base, otherwise it is very similar to the female except for the usual antigeny, as is obvious from an examination of a male received from $\mathrm{C}$. W. Howard who sent specimens of this species to the U. S. Department of Agriculture, Bureau of Entomology, that were reared from Sesamia fusca in Portuguese East Africa.

Type.-Apanteles sesamiæ Cameron.

\section{Family ICHNEUMONID无.}

\section{ANEMPHERES DIAPHANIE, new species.}

Female.-Length $8.5 \mathrm{~mm}$. Upper edge of scrobe apparently not reflexed nearly as far from the anterior ocellus as the outer edges of the lateral ocelli are from each other, front rather uniformly rugulose, antennæ 38-jointed, scape and pedicel yellowish beneath; dorsulum covered with whitish pubescence, tegulæ not prominently elevated, ridge bounding prepectus of mesothorax poorly developed or rudimentary above, episternum of mesothorax almost smooth and polished in part posteriorly, propodeum with only the basal three sides of the areola developed, no other raised lines present except the poorly developed upper lateral boundary of petiolarea, sulcus of propodeum very shallow, linear, transversely striate, spiracles nearly round, mid-coxæ tipped with yellow, mid-trochanters yellow, midfemora mostly brownish, hind trochanters yellow, their femora and tibiæ reddish brown, longest spur of hind tibiæ straight, wing membrane nearly colorless, tinged with fuscous, veins and stigma blackish, second abscissa of cubitus longer than the third, nervellus not broken; abdomen in profile clavate, petiole smooth and rounded without carinæ or fossæ, distance from base of petiole to spiracle more than twice that from spiracle to apex, petiole from a little before spiracle to apex bullous and reddish, rest of petiole black; second dorsal segment black and reddish, apical margin black, smooth except for a fine carina between base and thyridia, the latter longer than wide and about as far from the base of the segment as from each other, rest of abdomen reddish except for a blackish area at base of third segment.

Otherwise very similar to Campoplex oxyancanthæ Boie.

Type.-Female, Cat. No. 13485, U.S.N.M.

Type-locality.-Raleigh, North Carolina. "Bred from pupal cases of Diaphania hyalinata, October 15, 1909. Under N. C. Exp. Sta. Col., Cat. No. 56.25. Received by the U. S. Department of Agriculture, Bureau of Entomology, from Prof. R. S. Smith. 
CREMASTUS HYMENIAE, new species.

Judging from the accepted classification of Ophioninæ this species should not figure as a Cremastus because the occipital ridge is not broken and the radial cell extends more than halfway between the stigma and tip of the wing. In other particulars it is so closely similar to the genotype of Cremastus that I am constrained to give it this position.

Female.-Length $6.5 \mathrm{~mm}$.; stramineous, head with a broad blackish stain extending from the occipital foramen to the scrobes, orbits, malar space and clypeus yellow, rest of head mostly stramineous, dorsulum with three brownish areas; areola poorly defined below the costulæ, finely sculptured and dull, the sculpture similar to that of the other areas of the propodeum; wings hyaline, most of veins and stigma dark brownish; postpetiole and second tergal segment finely closely striated, petiole proper blackish, second tergal segment mostly blackish as is the third at base, exserted portion of sheaths of the ovipositor about half the length of the tergum of the abdomen.

Male.-Similar to the opposite sex.

Type.-Cat. No. 13507, U.S.N.M.

Type-locality.-Oahu, Hawaiian Islands.

"Bred from Hymenia fascialis, August 16, 1910." H. O. Marsh, collector.

\section{Genus HYPERALLUS Foerster.}

The following species described under this genus would seem to differ from Foerster's description only in having the longer of the hind spurs at least half as long as the first joint of the hind tarsi. The thyridia of the second dorsal segment are not much more developed than in Scopesis. Assuming that the thyridia are not conspicuous in our species the same would be best received into Scopesis. Our species is apparently, however, sufficiently different from Scopesis to give Hyperallus standing as separate from Scopesis.

HYPERALLUS CALIRO $Æ$, new species.

Compared with Scopesis guttigera (Holmgren) Thomson, this differs as follows:

Female.-Length, $3.5 \mathrm{~mm}$.; front hardly depressed, first flagellar joint virtually as long as scape and pedicel combined, head black, dullish in front, polished behind, scape and pedicel yellowish, first and second flagellar joints rather stramineous, remaining joints more or less dark brown; clypeus mostly yellowish as are the mandibles, palpi stramineous or yellowish, posterior ocelli about as far from each other as from the nearest point on the eye, but nearer to the anterior ocellus than to each other; thorax shining, poorly sculptured; dorsulum brownish, more or less stained with blackish; prothorax mostly 
stramineous, tubercles and tegulæ yellowish as is the disk of the upper division of the mesepisternum, disk of scutel brownish as is the disk of the metanotum (postscutel), rest of thorax mostly black or blackish; propodeum black, the areola poorly or not at all satisfactorily defined, virtually confluent with the basal area and petiolarea, apical transverse carina well developed on each side of the median longitudinal carinæ, lateral carinæ virtually wanting, median longitudinal carinæ wanting or poorly defined where they bound the basal area; wings transparent tinted with brown, veins and stigma mostly dark brown, legs mostly stramineous, hind tibiæ with most of apical third blackish, hind tarsi mostly fuscous, fore and mid-coxæ and all trochanters more or less yellowish; abdomen shining; basal tergite granular, blackish except for the apical fifth which is mostly stramineous with two longitudinal carinæ; second tergal segment granular, with the apical two-fifths mostly stramineous as are the thyridia, remaining tergal segments smoother than the preceding, although more or less similarly colored, ovipositor not exserted.

Male.-Similar except for the thorax, which is almost entirely black and in the better developed carinæ of propodeum and first tergal segment.

Type.-Cat. No. 13504, U.S.N.Mi.

Type-locality.-Tallulah, Louisiana.

Received from the U. S. Department of Agriculture, Bureau of Entomology, under Hunter No. 1936, II, 14, 8-10-10, 7-12-10. Par. Catiroa amygdatina, R. A. Cushman, collector; additional data on specimens bearing the same number and locality are II, 10, 5-17-10, 4-16-10; II, 17, 9-4-10, 8-12-10, 9-7-10, 8-12-10.

\section{Genus CAMPOLETIS Foerster}

Type.-Limnerium (Campoletis) prodeniæ, new species.

LIMNERIUM (CAMPOLETIS) PRODENIA, new species.

Female.-Length, $5 \mathrm{~mm}$. Black, covered with silvery pubescence that obscures the tegument only on the face and there only when viewed in certain lights; cheeks in the middle hardly more than half as wide as the eye as seen from the side, malar line a little shorter than the mandibles are wide at base, clypeus depressed along the anterior margin which is smooth and polished in the middle where it is produced into a kind of lip approaching in character the anterior edge in Sagarites, lateral suture between clypeus and face appearing distinct owing to the apparent reflection of the lateral edge of the clypeus, scape partly brownish in front, rest of antennæ black or blackish, mandibles yellowish except apically where they are as usual more or less castaneous to blackish, palpi yellowish; inner edge of eyes slightly, shallowly impressed above the middle, greatest diameter of lateral ocellus hardly more than half as long as the ocel- 
locular line, lateral ocellar line a little longer than the greatest diameter of the lateral ocellus, postocellar line nearly one and one-half times as long as the lateral ocellar line; costulæ developed, extending to the lateral longitudinal carinæ, which latter are not well defined, basal area and areola nearly as in Limnerium oxylus Cresson except that the third abscissa of the median longitudinal carina is nearly parallel to its fellow of the opposite side, apical transverse carina poorly developed, more or less wanting, second abscissa of radius straight as compared with the first and a little more than one and one half times as long as the same, stigma nearly three times as long as wide or high, areolet mesochorine in shape, petiolate, nervellus angulate below the middle, the portion below the angulation postfurcal, hind claws apparently simple; tegulæ, base of wings, anterior, middle and distal posterior trochanters yellow, anterior and middle coxæ more or less brownish, hind coxæ black, proximal posterior trochanters mostly blackish, fore and mid-femora translucent brownish, hind femora castaneous, fore and mid-tibiæ translucent brownish with yellowish above except apically, hind tibiæ variegated with a yellowish band at base followed by a fuscous band then a yellow band, and finally with the apical third infuscated, tarsi more or less brownish; abdomen with a more or less developed apical brownish band to the dorsal segments and with the greater part of the sides of the compressed segments brownish, plica yellow infuscated.

Male.-Similar to the female. The type lacks entirely the apical transverse carine.

Type.-Cat. No. 13483, U.S.N.M.

Type-locality.-Mount Washington, Ohio.

The types were received from the U.S. Department of Agriculture, Bureau of Entomology, with the following legends: "Bred from Prodenia ornithogalli, August 21, 1909." H. M. Miller, collector.

\section{MEGARHYSSA GREENEI, new species.}

Female.-Length, $27 \mathrm{~mm}$; sheaths of the ovipositor $35 \mathrm{~mm}$. long; similar to Megarhyssa lunator (Fabricius Cresson), from which it may be distinguished by the maculation of the wings being confined to the basal half of the marginal cell and to the apical third of the discocubital cell and by the length of the sheaths of the ovipositor which compared with the length of the body are comparatively shorter than in Megarhyssa lunator (Fabricius, Cresson).

Male. - Similar in color with the female but with traces of infuscation along the basal vein; abdomen differing from that in Megarhyssa lunator (Fabricius, Cresson) in ground color, and in the third to seventh tergal segments lacking a median longitudinal furrow.

Type.-Cat. No. 13499, U.S.N.M.

Type-locality.-Harrisburg, Pennsylvania; female June 21, male August 22, 1908. Collected by A. B. Champlain. 
The paratypes are from Boonton, New Jersey, August 14, 1901, collected by Geo. M. Greene; Canada; Pequaquawaming Point, Baraga County, Michigan, "woods on maple," July 23, 1903, collected by Morgan Hebard; Indiana (Baker), No. 2002; Harrisburg, Pennsylvania, June 8, 1908, August 22, 1908, P. R. Myers, collector; New Haven, Connecticut, August 10, 1909, A. T. Bourne; Philadelphia, Pennsylvania, July 4, 1899, H. Skinner.

In the smallest paratype the body is $17 \mathrm{~mm}$. long and the sheaths of the ovipositor $22 \mathrm{~mm}$. long.

\section{MESOCHORUS INFERNALIS, new species.}

Female.-Length, $2.5 \mathrm{~mm}$. Related to M. scitulus Cresson, from which it may be distinguished as follows: Basal areas brownish, basal area about three times as wide at base as at apex and nearly four times as long down the middle as wide at apex, areola a little more than twice as long as wide between the costulæ, sides of areola basad of costulæ a little shorter than sides of areola beyond the costulæ and about twice as long as the areola at apex, petiolarea about as long as the areola, but twice as wide as the same, one-third as wide at base as at apex, the basal sides a little shorter than the apical sides; basal third of first abdominal segment stramineous, apical third partly castaneous, hind femora stramineous, hind tibiæ banded at base and apex with fuscous, their tarsi stramineous.

Male.-Similar to the female. Basal areas blackish; areola and second lateral area brownish; apical third of first abdominal segment black.

Type-Cat. No. 13480, U.S.N.M.

Type-locality.-Santa Maria, Texas. Received from the U. S. Department of Agriculture, Bureau of Entomology, under Webster, No. 4612. Reared in connection with Apanteles (Protapanteles) flaviconchoe Riley, which is probably its host. The date is March 15, 1909. Collector, T. D. Urbahns.

MESOCHORUS PATULUS, new name.

Mesochorus areolatus Viereck, Trans. Amer. Ent. Soc., vol. 29, p. 92, separate p. 91, 1903; not Provancher, Nat. Can., vol. 14, 1883, pp. 4, 5.

MESOCHORUS NIGRISIGNUS, new species.

Female.-Length, $3.5 \mathrm{~mm}$. ; exserted portion of sheaths of the ovipositor at least two-thirds the length of the first tergal segment; stramineous, shining, head and dorsulum tinged with brownish; pronotal groove not divided by a longitudinal median carina, areola pentagonal, its bounding carinæ sharply defined, but little more than twice as long down the middle as wide between the junction of the costulæ, the latter width nearly twice that of the areola on its shortest 
side; hind tibiæ whitish, brownish at base and apex; first tergal segment with gradually converging sides to the beginning of the apical two-thirds, beyond this point gradually widening so that it is at least twice as wide at apex as at base, smooth and polished; setting of the spiracles virtually not at all elevated to a higher plane than the rest of the segment, postpetiole with a shallow almost tearshaped fossa down the middle, second tergal segment with a deeply, triangularly emarginate black band immediately beyond the thyridia.

Type.-Cat. No. 13509, U.S.N.M.

Type-locality.-Grand River, Iowa.

Presumably parasitic on Microplitis metianæ Viereck. "From Meliana albilinea, Experiment 500, July, 1910." R. L. Webster.

PHYGADEUON (BATHYMETIS) PATULUS, new species.

Male.-Length, $7.5 \mathrm{~mm}$. Compared with the description of Phygadeuon (Mastrus) neodiprioni Viereck as given below this species differs as follows: Face shining, with rather clearly defined punctures, clypeus with a testaceous mark on each side, antennæ 30-jointed, flagel brownish throughout, darker above on basal half and throughout beyond the middle than above at base; tegulæ yellow, coxæ and trochanters of fore legs and trochanters of middle legs mostly yellow, fore tibiæ and tarsi virtually stramineous, middle lateral area ribbed with rather prominent rugæ; tergum smooth, polished, almost sculptureless throughout.

Type.-Cat. No. 13506, U.S.N.M.

Type-locality.-Crawford, Nebraska.

"Bred from a Diprionid July 18, 1910." M. H. Swenk.

Genus DAICTES Foerster(=ISOTIMA Foerster.)

The following species is regarded by the writer as an Isotima with an areolet, as is found in Hemiteles Gravenhorst, strictly speaking. As it agrees with the diagnosis of Daictes Foerster except in having an incomplete areolet and the latter name has page precedence, it is proposed to regard it as a Daictes Foerster and assign it as a subgenus of Phygadeuon at present, it being apparently a Phygadeuonine in spite of the conformation of the areolet. Compared with the genotype of Stiboscopus (Foerster) Ashmead, Stiboscopus thoracicus Ashmead, the description of Daictes will read as follows:

Antennæ thickened so that the first flagellar joint is hardly more than three times as long as thick at base, greatest width of head back of the eyes, as seen in profile as great as the corresponding width of the eyes seen from the same point of view, distance from the antennal line to the apex of clypeus about as great as the distance from middle of face to eye margin; apical transverse carina S0796 - Proc.N.M.vol.40-11-13 
angularly produced into a flattened process where it joins the lateral longitudinal carina, costulæ poorly developed almost lost in part among the sculpture, first abscissa of the discoidal vein as long as the remaining abscissæ combined, the side of the stigma adjoining the disco-cubital cell almost half again as long as the side adjoining the radial cell; spiracles of first tergal segment prominent, the same segment with a distinct carina extending from the spiracles to the apex of the segment.

\section{PHYGADEUON (DAICTES) FUKAII, new species.}

Female.-Length, $5.5 \mathrm{~mm}$; head black, dullish, indistinctly punctured, scape and mandibles black, shining as is the clypeus, pedicel blackish, first, second, and third joints of the flagel brownish, remaining flagellar joints black or blackish, lateral ocellus a little nearer the anterior ocellus than to the eye margin, palpi stramineous, infuscated; thorax black and shining, indistinctly punctured, tegulæ brownish, wings suffused with brownish, veins dark brown, stigma dark brown except at base, where it is yellowish, fore wings yellow at base, legs mostly reddish brown, coxæ black, tibiæ and tarsi stramineous, infuscated, proximal trochanters more or less blackish, distal trochanters more or less concolorous with femora; propodeum black, shining, indistinctly punctured, the fused angular area and third lateral area rugose; first tergal segment black and polished, the dilated portion finely aciculated, second and third tergal segments reddish, polished, more or less indistinctly sculptured, remaining tergal segments black, polished, almost sculptureless, sheaths of the ovipositor blackish, about as long as the first tergal segment.

Type.-Cat. No. 13498, U.S.N.M.

Type-locality.-Konosu, Saitama, Japan.

T. Fukai, collector.

Named for Mr. T. Fukai.

Genus MASTRUS Foerster.

The species to be described below is evidently a Phygadeuonine with an incomplete areolet. In Foerster's classification this would go to Leptodemas on condition that the areolet be ignored. Now the genotype of Leptodemas would appear to be L. cariniscutis Cameron as that is the first species to be included under Leptodemas to the knowledge of the writer. Accordingly the description of Leptodemas Foerster is amplified through Cameron's description of Leptodemas cariniscutis Cameron. As the Leptodemas Foerster, Cameron has the scutel carinate laterally on the basal half and the wings with a complete areolet, which is not the case in the following species, it is deemed unwise to call it a Leptodemas Foerster, Cameron. In 
Foerster's classification of the Hemitelini where our species would go on account of the incomplete areolet we find that it attaches itself to Mastrus Foerster. As Mastrus has as yet no species in it we propose to take the liberty to include our species and transfer Mastrus to the Phygadeuoninæ near Leptodemas.

PHYGADEUON (MASTRUS) NEODIPRIONI, new species.

Female.-Length $6 \mathrm{~mm}$.; exserted portion of sheaths of the ovipositor about two-thirds the length of the tergum, head black and shining except for the face which while black is dullish and mostly closely punctures, the punctures not clearly circumscribed, basal half of mandibles mostly testaceous, the apical half mostly castaneous margined with black; antennæ 27 -jointed, from testaceous to brownish beneath, fuscous above, palpi mostly stramineous; thorax black and shining, tegulæ brownish, wing base yellow, wing transparent tinged with brown, most of veins and most of stigma blackish, coxæ and trochanters the color of brownish amber, femora, fore and midtibiæ reddish, hind tibiæ reddish tinged with brown, tarsi mostly brownish; propodeum black and shining, poorly sculptured except in the confluent angular and third lateral areas where the sculpture consists of coarse rugæ; first tergal segment black on its basal half becoming reddish tinged with black beyond, first tergal segment beyond the spiracles, or the postpetiole, longitudinally striated laterally; second tergal segment reddish, shining, the apical two-fifths depressed and very smooth, the basal three-fifths not depressed and granularly sculptured; remaining tergal segments smooth and polished almost sculptureless, the third and fourth brighter red than the preceding; fifth reddish suffused with black at base, blackish apically margined with stramineous; sixth segment blackish margined with straminoeus; seventh segment blackish except in most of its middle third where it is membranous and stramineous, sheaths of the ovipositor blackish, ovipositor mostly translucent reddish brown.

Type.-Cat. No. 13505, U.S.N.M.

Type-locality.-Crawford, Nebraska.

"Bred from a Diprionid July 18, 1910." $\quad$ M. H. Swenk, No. 1.

\section{Genus TOXOPHOROIDES Cresson.}

Type.-Lycorina? apicalis Cresson.

Related to Lycorina Holmgren but differs especially as follows: Apical joint of antennæ as long as or longer than the two preceding joints combined; scutel rounded off at apex and narrower at apex than long down the middle; propodeum without a basal area and with only the arcuate transverse carina ${ }^{1}$ fully developed, no other

In the male as represented by Glypta xanthozonata-Ashmead, even this carina is incomplete. 
carinæ present except the median and lateral longitudinal carinæ which latter are much abbreviated and arise at the apex of the sclerite but do not attain a point anywhere near the middle of this segment, basal segment with a flaring buttress on each side of the basal half of the segment, the basal segment not at all channeled down the middle; apical joint of hind tarsi shorter than the two preceding.

Still another species of Toxophoroides is Glypta scitula Cresson. 


\section{$2 \mathrm{BHL}$ Biodiversity Heritage Library}

Viereck, Henry Lorenz. 1911. "Descriptions of six new genera and thirty-one new species of ichneumon-flies." Proceedings of the United States National Museum 40, 173-196.

View This Item Online: https://www.biodiversitylibrary.org/item/53820

Permalink: https://www.biodiversitylibrary.org/partpdf/53269

\section{Holding Institution}

Smithsonian Libraries

\section{Sponsored by}

Smithsonian

\section{Copyright \& Reuse}

Copyright Status: Public domain. The BHL considers that this work is no longer under copyright protection.

This document was created from content at the Biodiversity Heritage Library, the world's largest open access digital library for biodiversity literature and archives. Visit BHL at https://www.biodiversitylibrary.org. 